\title{
Tax COMPliance and behavioural ReSPOnSE in South Africa: AN ALTERNATIVE INVESTIGATION
}

\author{
Rebone Gcabo \\ Department of Psychology, University of Pretoria
}

Zurika Robinson

South African Reserve Bank

\begin{abstract}
Taxpayer behaviour has in South Africa moved to the forefront of the investigation of revenue collection with regular tax awareness campaigns being launched by the South African Revenue Service (SARS). Issues relating to tax amnesty and the contribution of the informal sector (second economy) to tax revenue have become important. This paper attempts to find explanations, be they economic or psychological, for taxpayer behaviour in South Africa. Factors influencing tax evasion and ultimately collection targets are thus examined. A questionnaire was designed to determine how individuals, in this case a sample of students, respond when filing taxes. Each question frames a scenario to invoke a specific tax regime.

The paper's unique findings show, generally, that behaviour is to a large extent determined by economic factors, specifically inequality as predicted by the expected utility theory. This theory also successfully predicts 50 per cent of the responses to the control questions. The remaining 50 per cent are explained by combined economic and psychological factors, modelled by the prospect theory. This is significant considering the fact that the results were generated within a developing and not a developed context as is the case in most studies of this type.
\end{abstract}

JEL H21, 047

\section{1 Introduction}

Finding the correct explanation for tax evasion can be challenging particularly in the context of a developing country. Issues such as tax literacy (theoretical and practical knowledge of tax systems) and societal attitudes towards tax compliance must be explored. Tax awareness and behaviour have long been debated globally among academics and economists, and performanceorientated revenue authorities have become a familiar sight worldwide. In South Africa, the South African Revenue Service (SARS) has an unprecedentedly successful and unmatched record since its establishment in 1997. It had consistently surpassed tax collection targets (NTSA, 2003), which suggests that the country's tax administration will only become more efficient and transparent overall, with reduced levels of tax evasion, although the tax gap still exists (SARS, 2004). Backlogs appear to have been cleared to a large extent and tax morale improved. Tax amnesty and awareness campaigns have been launched by SARS, including informal sector participants (thus improving the so-called second economy's contribution). In these efforts factors influencing tax collection have assumed greater and greater importance, although as yet little research has been conducted to explore the links between improved revenue collection in South Africa and enhanced confidence in the government on the part of citizens (positive citizen attitudes).

This paper is thus the first attempt in the South African context to address this gap. It uses a slightly unusual approach, known as the prospect theory of behavioural response, to 
explore tax evasion and compliance. This theory takes societal attitudes, emotions, feelings and/or perceptions about taxation in general as its base. Economic, psychological and social factors are then considered as determinants of tax compliance or evasion. The theory incorporates two different approaches. On the one hand, psychological theory views tax regimes in terms of equity, postulating that when regimes are considered fair, compliance will be high. On the other hand, traditional economic theory assumes that rational agents maximise their expected utility (this despite the fact that behavioural studies have long shown that individual responses are inconsistent with the theory; individuals make systematic 'mistakes', for instance, choosing to comply with a tax regime even though expected utility might expect them to cheat). The prospect theory attempts to combine these two approaches, within the bounds of unavoidable constraints of course, as an alternative way of studying tax evasion.

This paper is divided into three sections. The first section gives the background and purpose for the research, including a theoretical overview of potential factors determining tax evasion. These factors can be either economic or psychological. The second section investigates the empirical results. The last section concludes with a summary of the results and suggestions for further research. This paper is actually thus a stepping-stone for further research of this nature, specifically in the context of a developing country.

\section{2}

\section{Background and purpose}

The tax gap is defined as the difference between the expected and actual revenue generated by tax authorities. The gap exists firstly because individuals and business understate their incomes; overstate deductions, credits or exemptions; or make calculation errors on their returns. Secondly, some taxpayers do not file the required returns or file these after they are legally due. Finally, tax authorities sometimes make errors in assessment. In South Africa, the tax gap has ranged from as low as about 10 per cent to as high of 33 per cent or more (Katz Commission, 1994).

Before addressing specific factors that could possibly influence the tax gap, such as taxpayer behaviour (including tax evasion), it is essential to look at changing tendencies in the global tax environment. In the global economic environment, income tax bases are continuously thinning as governments' ability to tax capital flows deteriorate. In addition, since the bulk of revenue is collected from income tax, especially corporate tax, in developing countries, the protection of the individual and the corporate tax base has become crucial. The so-called vanishing taxpayer or tax entity has become a force to be reckoned with (Economist, 2000). As the developing world becomes more deregulated and integrated, following in the footsteps of its industrialised counterparts, it is imperative that tax strategies and/or tax policies be appropriately designed and continuously monitored so as to optimise revenue collection and ultimately support the strategies of revenue authorities. Rapid advances in computer and telecommunications technology and a new emphasis by professional firms on the development and marketing of so-called tax products might in future re-define traditional tax evasion as 'avoidance measures'.

Lower corporate tax burdens worldwide could relate to the apparent shift away from corporate taxation (internationally mobile tax bases) to individual income taxation and commodity taxation (which are perceived as the less mobile tax bases). Disconcertingly, in some countries this shift has resulted in an overall reliance on individual taxes rather than on corporate taxes. With labour becoming more mobile, especially skilled labour from developing countries (World Bank, 2000) and general consumption taxes becoming the fastest growing revenue source, the future protection of the individual income tax base as revenue generator must be emphasised.

A higher degree of world economic integration has also resulted from the unification of many currencies, such as the introduction of the euro. This widens the scope for harmful practices such as tax competition even further (see EC, 1997 and OECD, 1998). Taxation therefore remains 
an important feature of unification and often affords countries an opportunity to export part of their tax burden to other countries (Tanzi, 1996: 20). This obviously creates the possibility of abuse, such as the utilisation of tax addresses in tax havens, and/or the shifting of operations or use of transfer pricing by multinational corporations (MNCs) with the financial capacity to try these tax avoidance methods. Such practices to lower tax bills through tax avoidance and evasion have also become widespread among individual tax payers.

\subsection{Overview of factors determining taxation}

Before investigating tax evasion further, the possible factors determining taxation in general and influencing the South African tax system specifically must be clearly understood.

From the earliest times there have been different views on the impact of taxes. Smith (1776) points out that 'high taxes frequently afford a smaller revenue to government than what might be drawn from more moderate taxes'. Supply-side economists go further, raising concerns about how taxes can discourage private savings and investment. The debate is ongoing, and different assumptions are used in various models.

One of the best known of these models, which explains tax burdens, is the Laffer theory. This model places the optimal tax rate for a country somewhere between a zero and 100 per cent tax level; this optimum level will yield the highest return to government with the minimum excess burden to influence total output. Some studies therefore find that a tax cut may lead to increased government revenue depending on where the country lies on the Laffer curve. However, the Laffer theory is based on some debilitating assumptions that are problematic considering the dynamic setting of the revenue effects the curve attempts to predict. These are (a) the assumption that the government adheres to its original consumption and transfer programmes, despite the tax cut boost which may contribute to the growth rate of output, and/or (b) the assumption that the government is committed to maintaining its expenditure/ output ratio after the tax cut.
This example shows how problems can arise in attempts to analyse the impact of taxation on various variables. The assumptions made in some studies may need interrogation, necessitating study not only of financing needs but also of expenditure realities. Further, although higher tax levels can reduce growth rates in a developing environment, this is extremely difficult to research systematically and coherently (Newberry \& Stern, 1987: 13). The definition of economic growth and the delineation of the factors that influence it (e.g. aggregate demand) are of crucial importance in studies of this nature. Also, effective tax rates should be taken into account. These are determined by a number of variables such as statutory tax rates, deductibility of interest, depreciation allowances, special investment incentives and the integration of personal and corporate income taxes. When different types of investment are considered, no general conclusion can be drawn about which country has the highest tax burden (OECD, 1991). Calculating the effective tax rate for multinational investment is even more complicated. It depends on whether foreign source income is taxed in the host country, or in the home country of residence, or in both. The intricacies involved in the determination of the precise effects of changing taxes and simultaneous changes in the tax base are enormous (see UNCTAD, 1998).

The theory of optimal taxation is a purely normative theory and does not specifically allow for a separate analysis of, for example, corporate income taxes. Undoubtedly this relates to the complex nature of corporate taxes. The theory also does not predict what a real-world tax system should look like nor does it explain how these tax systems emerge. However, it does clearly explain the tax mix. Conventional theory argues for a tax mix that is as diverse as possible. The tax system should therefore not rely on only one type of tax, since this could weaken the system in the long term. Taxation involves social marginal costs of public funds (SMCPF) and the more diverse the tax mix, the lower the costs will be. Tax revenues should therefore be collected from a wide variety of taxes. On this point, optimal commodity tax theory puts forward 
similar arguments, the inverse elasticity rule for instance, although the reverse application of this rule is advocated in a developing context.

The theory of optimal taxation, however, does not address the broad application of corporate income taxes. The only extensive theoretical analysis here relates to behavioural responses of companies to corporate taxes (see Jorgenson, 1963). But again, this analysis (the Neoclassical Model), does not include factors influencing corporate income taxes, rather focusing on the reverse, that is, the effect of corporate taxes on various factors, such as user cost of capital. Investigating corporate income taxes, which in this study is taken as referring to statutory and average corporate income tax (CIT), must thus begin with an extensive description of all the factors that could influence the determination of this type of tax. Firstly, CIT rate and revenues could be expected to rise as government spending (relative to GDP) or revenue (developmental/social security) needs increase over time and across countries. If this is not the case, CIT will be determined by a range of alternative factors.

Governments operate in a market system alongside the private sector in financing and providing services, and may by their very actions distort the decisions of the private sector. The conventional belief that taxing income entails a higher welfare (efficiency) cost than taxing consumption is primarily based on the observation that income tax consists of two broad components, namely labour tax and capital tax. Since labour tax is equal to a tax on consumption in an inter-temporal framework, income tax gives rise to an additional distortion, distortion of savings, which is absent from the commodity tax. In the traditional neoclassical growth model, the length of the consumer's planning horizon plays a crucial role in the theoretical ambiguity of the relative superiority of commodity tax. If saving decisions are based on life-cycle considerations, the optimal mix of income and commodity taxes will depend entirely on relevant elasticities, that is, of labour supply and savings. In contrast to this model, new endogenous growth theory adds a crucial component, human capital, to the analysis, which complicates the analysis and makes results relatively more ambiguous (Tanzi $\&$ Zee, 2001).

It follows that an optimal tax structure must be designed within the analytical framework of a second-best world (Frenkel, Razin \& Sadka, 1991: 99). The theory of second best is applicable where multiple tax instruments are available. It holds that policies which in isolation would increase tax efficiency can in the presence of certain distortions actually decrease it and vice versa. Finding the benchmark for optimal taxation starts with the aggregate production efficiency theory (Diamond \& Mirrlees, 1971). According to this theory, assuming that the government is not constrained in its choice of tax type, an optimal tax structure is one that does not distort production decisions. Such a structure minimises output, which is then divided between consumption and government spending. The existence of tax differentials will therefore usually have a distorting effect on savings and investments between regions.

The implication of this aggregate production efficiency theorem is that the source principle is always inferior to the residence principle, which alone guarantees the absence of distortions in individuals' investment and production choices. In this model, tax principles, also called tax assignment rules, determine the jurisdiction of the national tax rate over capital income and commodities. These principles determine both the distribution of tax revenues between regions and the tax rate that is levied on international investment and trade. In the absence of lumpsum taxes, therefore, this model predicts that tax policy is optimally chosen in an open economy when the country operates on its consumption possibility frontier and does not distort production (Dixit \& Norman, 1980; Frenkel, et al., 1991). This result rests on some strict assumptions, firstly, that the government's choice of taxes is not constrained in any way and secondly, that foreign countries do not react to tax reforms. This can only be true when the country reforming its tax is small and the change has a negligible effect on prices in all markets.

With this theoretical base, we next turn to tax legislation in South Africa and more specifically those measures that provide for the treatment of tax evasion. 


\subsection{Tax legislation in South Africa}

Tax evasion is difficult to analyse and measurement practices are dogged by imprecision and controversy (see Schneider \& Enste, 2000). ${ }^{2}$ The OECD (2002) launched an investigation into the similarities between the techniques used to commit tax crimes and those used to launder the proceeds of other crimes. The findings show that money laundering regulations cover crimes involving fiscal fraud or other tax crimes in more than half of the 28 member countries involved in the survey. The OECD report therefore recommends the release of information gathered by anti-moneylaundering authorities to tax authorities. Again, the vanishing taxpayer is a concern, suggesting that a 'World Tax Organisation' could assist with tax cooperation and harmonisation worldwide.

In South Africa, section 103 of the Income Tax Act (Act No 58 of 1962) differentiates between tax evasion on the one hand and tax avoidance and tax planning on the other. Tax evasion is based on the non-disclosure of information to the tax authorities in an effort to evade tax. Impermissible tax avoidance involves contrived arrangements that are designed to exploit perceived loopholes in tax law. Permissible tax planning involves finding the most advantageous option in the tax legislation but accepting all the economic and legal consequences of that option.

In 2005, an announcement was made by the National Treasury of South Africa (NTSA, 2005) which called for an overhaul of the general antiavoidance rule in section 103 of the Income Tax Act, which was considered to be outdated. The SARS released a discussion paper exploring the details of this overhaul. The paper discusses short-term revenue loss as an immediate concern, as well as the following:

- a growing disrespect for the tax system and the law,

- a corrosive effect on taxpayer compliance,

- increasingly complex tax legislation and a concomitant increase in the compliance burden for everyone,
- the uneconomical re- or misallocation of resources,

- an unfair shifting of the tax burden, and

- a weakening of the ability of Parliament and National Treasury to set and implement economic policy.

The paper also mentions legitimate countervailing measures in an attempt to strengthen the antiavoidance rule. These measures include, among others, increased uncertainty for taxpayers, inhibition of legitimate and/or innovative transactions, and the 'uneasy tension' that exists between the general anti-avoidance rule and the rule of law (subjectivity versus objectivity).

As possible solutions for these problems, the paper suggests major changes to section 103 of the Income Tax Act including the introduction of new penalties for scheme promoters and for taxpayers who substantially underreport their income, and simplification and clarification of the regulations. However, we suggest in this paper that revenue authorities must also reconsider the economic and psychological factors behind tax evasion. Answering the question of why taxpayers underreport their income might be more important than inventing new penalties.

\subsection{Economic reasoning behind tax evasion}

One of the earliest of the theories that try to provide a suitable explanation for tax evasion, the expected utility theory, describes decisionmaking in terms of uncertainty. Decisionmakers are viewed as rational and their preferences as determined by various utilities, such as transitivity, dominance and invariance. These utilities are weighed by their respective probabilities and individuals maximise their expected utility subject to certain assumptions or constraints. While expected utility theory assumes that taxpayers are averse to risk (Von Neumann \& Morgenstein, 1944), various other possibilities have been recognised with the main criticism that the characteristics of transitivity, dominance and invariance do not always apply (see Tanzi \& Shome, 1993; OECD, 1991, 1998 \& 2002; Kirchler \& Maciejovsky, 2001). 
Tax evasion has typically been explained using economic theory. Within this theoretical framework, tax evasion behaviour is described as a function of the probability of detection and the size of the penalties imposed. Trivedi, Shehata and Mestelman (2005) indicate that the efficacy of increasing penalties and audits on tax evasion depends on the reasons why taxpayers comply or fail to comply. Their report suggests that economic approaches to describing and predicting taxpayer behaviour alone are not adequate and that further research could be based on social psychology. Since the seminal economic study on tax evasion by Allingham and Sandmo (1972), a wealth of research has been published which focuses on psychological explanations of tax evasion, some of it in the context of developing countries. One approach is to use behavioural and experimental measurement instruments that correlate better with self-reported tax evasion.

\subsection{Psychological reasoning behind tax evasion}

The first group of theoretical explanations concentrates on social comparisons. Individuals compare their situation with other groups and select information from 'similar others'. Vogel's study (1974) is important in this field. It distinguishes between internalisation, identification and compliance, and specifies three objective factors that help determine evasion, namely the individual exchange relationship with the government, social orientation and opportunities for evasion. These factors are found to have both direct and indirect effects on tax attitudes and evasion. This study is thus an important early attempt to focus on the moral dimension of taxpayer behaviour and to deal with individual differences in this behaviour.

Kinsey (1984) concludes from his survey of relevant literature that underreporting of income is the most popular form of tax evasion. Smith and Kinsey (1987) describe a conceptual framework for understanding taxpayer behaviour. They distinguish between the process and content of decision-making, and emphasise that people do not take a single decision to evade tax. Evasion involves a series of actions, such as deliberately 'forgetting' to submit tax returns or mentally redefining some earnings as non-taxable. These actions form a process which moves people from their habitual compliant response to a conscious decision to evade tax or cheat. During this process, people who choose to cheat tend to weigh certain specific factors such as material consequences, normative expectations, socio-legal attitudes and expressive factors.

Material consequences and normative expectations are most important of these factors. The rapidity with which consequences are felt and the private nature of taxpaying, which limit the impact of normative expectations, must be considered in the design of any evasion prevention measures. If the evader just has to keep quiet to avoid consequences, only guilt can possibly trouble him/her, since there is little to fear in terms of public shame. The other two factors, socio-legal attitudes and expressive factors, are less often included in analyses of tax evasion. Of these factors, attitudes towards government spending and the tax system are most significant (also see Kirchler, 1998).

Elffers and Hessing (1997) approach tax evasion as defective behaviour within a social dilemma, which involves what is best for the individual and the group. Their methodology is worth mentioning for possible future testing in South Africa. In the case of tax evasion, an individual will benefit if that individual alone evades tax rather than if more people evade tax. This social dilemma mostly occurs when there is a considerable increase in tax caused by an increase in non-payment in some areas, such as in the case of small/micro/medium enterprises and taxi industries where self-employed trades and professions persist, i.e. where income is not affected by the paying or withholding of tax and various warranted expenses are deductible. This may in return, fuel resentment and non-payment in future. However, the determinants of taxpayer behaviour need to be interpreted with caution, depending on the method of assessment used. Both attitudes and personality characteristics can account for taxpayer behaviour. It also appears that a greater opportunity for tax evasion is associated with self-reports, which 
indicates that attitudes and subjective norms are significantly correlated with tax evasion.

Social dilemma research focuses on the motivational orientation of taxpayers, whether individualistic, competitive or co-operative. Two theoretical variables are proposed, namely instigations and constraints, found in an individual and his/her social setting. For example, financial strain or the amount owed after underreporting (see Warneryd \& Walerud, 1982) is a situational instigation and its opposite psychological counterpart is personal strain or difficulty in meeting the tax obligations and perceived unfairness of tax laws and authorities (see Lewis, 1982; Groenland \& Van Veldhoven, 1983). Thus in this model the variables occur in mirror pairs. Social conditions or social norms mirror psychological conditions, for example a personal orientation, which is a self-serving rather than a community orientation, will lead to tax evasion behaviour (also see Carroll, 1992).

The second group of theoretical explanations for tax evasion concentrates on equity. Individuals evade taxes to restore balance or equity in the tax system. Klepper and Nagin (1989) stress two tendencies in the taxpayer's mental makeup. Firstly, taxpayers will usually not take risks even if they can clearly see the best outcome resulting from this risk. Secondly, taxpayers prefer to be lazy and procrastinate anyway even when reminded about deadlines all the time. According to Lewis, Webley and Furnham (1995), tax evasion is a moral question, since we create inequities by evading taxes. In general, this approach assumes that paying tax is never popular, even when taxpayers recognise it as legitimate and the government expenditure it will finance as highly desirable. It is unlikely that human disposition will change in this respect.

\subsection{Alternative explanations for tax evasion}

Kahneman and Tversky (1979) provide an alternative explanation for tax evasion behaviour in the form of the prospect theory. Tvede and Ghiglino (1999) refer to this theory as one of the most influential and best-documented phenomena in economic psychology. Prospect theory is based on the assumption that people evaluate gains or losses from some neutral status quo as reference point. People are not rational decision-makers at all, but instead tend to adapt to any constant in their lives until they find this constant neutral. Thus when people expect a profit from the taxman, they will opt for risk-avoidance behaviour in the form of a safe, risk-free strategy to collect the profit by returning their tax return forms as soon as possible. However, if they are expecting a loss, they become risk takers by suppressing part of their taxable income to the verge of or just over the limit of what is permissible.

These economic and psychological theories can be tested in various ways to assess which one best explains taxpayer behaviour. One approach is to study the impact of the implementation of legislative changes. Another approach, which is used in this study, is to ask actual taxpayers (students), with the goal of finding the best way to study tax evasion behaviour and to form a theory which best explains this behaviour. Since considering all existing economic and psychological theories is beyond the scope of this paper, certain relevant theories have been chosen.

\section{3}

\section{Methodology and explanation of main findings}

The case study or experiment was conducted at the University of Pretoria, Pretoria, and 195 students participated in the study. The use of students in experiments and surveys is common (see Alm et al., 1993; King \& Sheffrin, 2002). Participation in the study was voluntary. The students were undergraduates. We asked them four questions relevant to the research topic. Each question was introduced by a framing scenario, which focused the question on a particular aspect of tax behaviour. The answers were compared with the assumptions and predictions of prospect theory; if they differed, better matches were looked for in alternative theories, namely social comparison, exchange equity and expected utility theory, and, where possible, in alternative explanations to these existing theories. 
To avoid any possible disadvantages of using students as subjects in this study, we included a control question (included in the appendix) for each real question to isolate the effects of the framed tax situation in the experiment. The controlled questions were presented to participants as casino gambles and therefore had no apparent link to the framing scenarios of the real questions. In this way, the differences in the responses could be attributed to the frame.

The questionnaire was entitled: 'Questionnaire to determine which theory best explains the public's tax behaviour', and introduced with this paragraph:

In most countries there is disagreement on the fairness of the tax system. In South Africa, some taxpayers feel that the tax system is unfair, e.g. because unnecessary expenditure on arms places a large burden on the public. However, many feel that South Africa has a fair tax system because the tax base is wide enough so that individuals pay a fair amount of tax. Choose between either (a) or (b) and (c) or (d) for each question by ticking the appropriate box.

The questions were split into two groups, namely Group A, the framed questions for Questions 1-4 and Group B, the control questions for Questions 1-4. Thus each framed question had a control question. Question 5 was a general question.

Each question will now be presented with its results and a possible explanation of these findings. Table 1 presents a summary of the responses to Questions 1-5.

Question 1 investigates the certainty effect and social comparison theory.

The SARS reports that tax evasion among those with incomes in excess of R500 000 is at an all-time high, and the SARS does not have the resources to investigate and punish all these evaders. Imagine that this year you have high medical expenses that you thought would count as allowable medical deductions. However, when you file your return, you discover that the expenses are not high enough to qualify for deductions. This means that your tax bill is R1 000 higher than you expected. You are preparing your tax return.

Which option, a or b, do you prefer?

a) Claiming an allowable tax deduction that will save you R500 in taxes

b) Claiming a 'non-allowable' deduction that has an 80 per cent chance of being accepted by the SARS, and which saves you R1 000 in taxes

Which option, c or d, do you prefer?

c) Claiming a deduction that has a 25 per cent chance of being accepted by the SARS which saves you R500 in taxes

d) Claiming a deduction that has a 20 per cent chance of being accepted by the SARS which saves you R1 000 in taxes

In this question, options c) and d) are similar to a) and b) but exaggerated by 25 per cent. According to prospect theory, individuals are more averse to losses that are certain than to losses that are probable, even if the probable loss has a higher mathematical expectation. Prospect theory therefore predicts that individuals will choose a) and d) because of the certainty effect. Equity theory predicts that individuals will choose b) and d) because individuals attempt to restore inequity in the tax system, that is, they originally perceive the system as unfair. 


\section{Table 1}

Summary of mean responses to all questions

\begin{tabular}{|l|c|c|c|c|}
\hline & \multicolumn{4}{|c|}{ Mean Responses } \\
\hline Question & $1(\mathrm{a})$ & $1(\mathrm{~b})$ & $1(\mathrm{c})$ & 1 (d) \\
Framed & $54 \%$ & $46 \%$ & $37 \%$ & $63 \%$ \\
Control & $77 \%$ & $23 \%$ & $28 \%$ & $72 \%$ \\
Significance Ho: Framed = Control & 1.3 & & 3.16 & \\
P value & $(0.24)$ & & $(0.00)$ & \\
\hline Question & $2(\mathrm{a})$ & $2(\mathrm{~b})$ & $2(\mathrm{c})$ & 2 (d) \\
Framed & $60 \%$ & $40 \%$ & $63 \%$ & $37 \%$ \\
Control & $74 \%$ & $26 \%$ & $57 \%$ & $43 \%$ \\
Significance Ho: Framed = Control & 1.2 & & 2.0 & \\
P value & $(0.18)$ & & $(0.00)$ & \\
\hline Question & $3(\mathrm{a})$ & $3(\mathrm{~b})$ & $3(\mathrm{c})$ & 3 (d) \\
Framed & $75 \%$ & $25 \%$ & $79 \%$ & $21 \%$ \\
Control & $64 \%$ & $36 \%$ & $55 \%$ & $45 \%$ \\
Significance Ho: Framed = Control & 0.4 & & 3.2 & \\
P value & $(0.64)$ & & $(0.00)$ & \\
\hline Question & $4(\mathrm{a})$ & $4(\mathrm{~b})$ & $4(\mathrm{c})$ & $4(\mathrm{~d})$ \\
Framed & $56 \%$ & $44 \%$ & $52 \%$ & $48 \%$ \\
Control & $62 \%$ & $38 \%$ & $43 \%$ & $57 \%$ \\
Significance Ho: Framed = Control & 1.2 & & 2.4 & \\
P value & $(0.30)$ & & $(0.00)$ & \\
\hline Question & $5(\mathrm{a})$ & $5(\mathrm{~b})$ & $5(\mathrm{c})$ & \\
\hline & $4 \%$ & $50 \%$ & $46 \%$ & \\
& $(\mathrm{n}=9)$ & $(\mathrm{n}=97)$ & $(\mathrm{n}=89)$ & \\
\hline
\end{tabular}

The response to Question 1 shows that participants tend to follow the prospect theory, though not overwhelmingly: 54 per cent of the participants chose option a) over b) and 63 per cent chose option d) over option c).

Question 2 investigates loss aversion and exchange equity.

Imagine you have just read a report that the SA General Accounting Office has found that the government spent R10 billion on missiles that cannot be used in South African equipment. This means that the government wasted R10 billion. You are preparing your tax return and at filing find that you under-withheld, and owe $\mathrm{R} 10000$ in taxes.
Which option, a or b, will you take?

a) Not reporting cash income, which will save you R1 500 in taxes

b) Not reporting income from defence stock dividends, which is 25 per cent likely to not save you any tax

Which option, c or d, do you prefer?

c) Not reporting cash income, which means you owe R8 500 in taxes

d) Not reporting income from defence stock dividends, which is 25 per cent likely to save to tax, and 75 per cent likely of making you liable for R10 000 in tax. 
Prospect theory indicates that people take risks when faced with loss and avoid risk when faced with gain, a phenomenon known as loss aversion. Choices a) and b) are identical to c) and d), except that a) and b) are framed as gains and c) and d) as losses. Therefore, a respondent who chooses a) should also choose c). Prospect theory predicts that individuals will choose a) and then d) because of loss aversion. However, equity theory suggests $b$ ) and d) since individuals attempt to restore inequity.

The results in Table 1 show that the respondents chose a) (60 per cent) and d) (63 per cent). This result is not consistent with prospect theory. The same result distribution is seen in responses to the control questions: a) (74 per cent) and d) (57 per cent). Respondents therefore acted consistently throughout and 'irrationally' as predicted by expected utility theory. The results are also consistent with equity theory. If the tax system is viewed as inequitable, this theory predicts that taxpayers will evade taxes in order to restore equity in the system. These choices also indicate that the respondents did not choose the safe option (not reporting) but preferred the risky option (not reporting income from defence stocks). That is, under inequitable situations, these individuals are willing to take risks to restore equity.

\section{Question 3 also investigates loss aversion and social comparison theory.}

Imagine that your co-worker informs you that he has been claiming a non-allowable deduction on his taxes and has never been caught. He further informs you that his brotherin-law, who works for the SARS, has been claiming the same deduction for years without a penalty. He says the probability of an audit is 10 per cent.

Which option, a or b, do you prefer?

a) Claim your usual deductions, which saves you R1 000 in taxes

b) Claim the 'non-allowable' deduction your colleague has described, which has a 33 per cent probability of a tax saving of R4 000 and 66 per cent probability of not saving you any tax
Which option, c or d, do you prefer?

c) Claim your usual deductions so that you owe R4 000 in taxes

d) Claim the 'non-allowable' deduction, which means you have a 33 per cent probability of owing R1 000 in taxes and 66 per cent probability of owing R5 000 in taxes?

Question 3 is similar to Question 2, but focuses on peer opinion and normative expectations rather than on exchange inequity (between the individual and the government). Previous work has found that individuals tend to seek advice from similar others such as co-workers (even if their tax situations are not the same). Moreover, advice about tax evasion methods sends a signal to individuals that tax evasion is acceptable, that is, that one will not be a social outcast if caught evading tax. Again, options a) and b) are framed as gains and options c) and d) as losses. Therefore, the same predictions would apply to Question 3 as to Question 2.

The results in Table 1 show that 75 per cent of participants chose a) and 79 per cent chose c), because options a) and c) are the same but framed differently. As for question 2, also, the responses to the control questions show a similar pattern: 64 per cent of participants chose a) and 55 per cent chose $\mathrm{c}$ ). There responses are again consistent with equity theory.

Question 4 investigates the certainty effect and exchange equity.

Suppose that in 2004 the government proposed to spend R10 billion on education. However, instead of voting for the education bill, Parliament voted for a bill that would prop up tobacco farms in KwaZulu-Natal. The newspapers report that heavy lobbying by the tobacco industry swayed the vote.

Which option, a or b, do you prefer?

a) Claim a tuition tax credit, which saves you R5 000 in tax

b) Claim tuition fees as a business expense, which has a 50 per cent chance of saving you R15 000 and a 50 per cent chance of not saving you anything 
Which option, c or d, do you prefer?

c) Claim a tuition tax credit, which has a 20 per cent chance of saving you R5 000

d) Claim tuition fees as a business expense, which has a 10 per cent chance of saving you R15 000 and a 10 per cent chance of not saving you anything

Options c) and d) are the same as options a) and b) except that their probabilities are multiplied by 20 per cent. According to prospect theory, individuals will choose a) and d) because they are more averse to losses that are certain than to losses that are probable, even is the probable loss has a higher mathematical expectation. Given that the scenario depicts inequity, participants may choose option b) over a) as they take risks to restore inequity. The results in Table 1 show that 56 per cent of participants chose a) over b) and 52 per cent chose c) over d). These results are similar to those of Questions 2 and 3. They are not consistent with prospect theory but rather with expected utility theory. For the first time in this study, however, the results from the control questions are consistent with prospect theory.

For the first four questions, the responses to the framed and control questions for options c) and d) differ significantly at the 1 per cent confidence level. It is thus clear that the only difference between the experimental/framed questions and the control questions are the inclusion of a frame depicting an inequitable situation. Therefore, the inequity frame alters how the participant responds to the question.

\section{Question 5 investigates the participant's} general disposition towards tax evasion.

General considerations regarding tax evasion:

Which option, a, b or c, would you prefer?

a) Cheating on your taxes

b) Cheating on your taxes under certain circumstances

c) Never considering cheating on your taxes

The majority of the participants in the experiment indicated that they would consider cheating on their taxes under certain circumstances, with 4 per cent choosing option a); 50 per cent option b); and 46 per cent option c). However, one cannot read too much into this result because only 4 per cent of the respondents indicated that they would cheat on their taxes. In this context, the results seem to be robust.

Thus this survey used a short introduction that framed a scenario to invoke an opinion of the tax regime as fair or unfair. Once the scenario is established, the next step was to determine how the individual will respond when filing taxes. The frame therefore differs according to what type of inequity is being measured (exchange or social). In the second stage, participants were asked to choose between different gambles. The gambles were structured so as to force participants to reveal their preferences. The purpose was to identify whether individual behaviour follows the pattern predicted by prospect theory, given a scenario that frames a perception of inequity. However, feelings of inequity or negative emotions driven by inferiority could induce actions that are incompatible with loss aversion or the certainty effect.

\section{4 \\ Concluding remarks and suggestions for future research}

This paper attempts to explore the psychological basis for tax compliance, framing compliance in terms of behavioural response. In South Africa, taxpayer behaviour has recently received increased attention following the launch of tax awareness campaigns by the revenue authority (SARS). Factors influencing tax collection such as behavioural response have become paramount for future policy-making.

The paper's results show a generally consistent response to the framing scenarios, reflecting in terms of economic factors the assumptions of the expected utility theory. In general, then, the responses to the framed questions are not consistent with prospect theory. Expected utility theory also explains 50 per cent of the responses to the control questions. The remaining $50 \mathrm{per}$ cent are explained by prospect theory. The responses to the control questions therefore conflict with those to the real questions, in that the control responses correspond with prospect theory. One may argue that South 
Africa has a tax-paying culture, unlike many other developing nations. The country does not suffer from tax revolts and protests, suggesting that in South Africa tax collectors benefit from a compliant culture built up over many years, which should be strong enough to ensure higher compliance when managerial methods improve. The outcome of any studies on tax evasion in South Africa may thus be expected to be more in line with results from a developed context.

The results of this study are exciting and unique because they open up further theoretical perspectives in the form of psychological explanations for tax compliance behaviour. Although the control questions do improve the robustness of the results somewhat, the main questions, because not intended to reveal participants' motivation towards a specific behaviour, did not explore the participants' decisions in any depth. Another limitation is that the participants were students, and so not necessarily experienced in tax practices. However, these limitations offer opportunity for future exploration. Taxpayers, both individuals and businesses, could be interviewed, at the beginning and at the end of the tax season, to show their thoughts and behaviour when filing tax forms and doing preparatory work.

\section{Appendix: Group B questions (control questions)}

1. Which option would you prefer?
(a) a sure win of R500
(b) an 80 per cent chance of winning R1 000
Which option would you prefer?
(c) a 25 per cent chance of winning R500
(d) a 20 per cent chance of winning R1 000

2. Suppose you already owe a casino R10 000 . You have a final opportunity to play the following game. Which of the following options would you choose?
(a) a sure gain of R1 500
(b) a 25 per cent chance of gaining R10 000 and 75 per cent chance of nothing

Which of the following options would you choose?

(c) not reporting cash income, meaning you owe R8 500 in taxes

(d) not reporting income from defence stock dividends, which has a 25 per cent probability of reducing your taxes and 75 per cent probability of making you liable to paying R10 000 in taxes

3. Suppose you already owe a casino R10 000 . You have a final opportunity to play the following game. Which of the following options would you choose?

(a) a sure gain of R1 500

(b) a 25 per cent chance of gaining R10 000 and 75 per cent chance of nothing

Which of the following options would you choose?

(c) claiming your usual deductions so that you owe R4 000 in taxes

(d) claiming the 'non-allowable' deduction, which means you have a 33 per cent probability of owing R1 000 in taxes and 66 per cent probability of owing R5 000 in taxes

4. Which of the following options do you prefer?

(a) a sure win of R5 000

(b) a 50 per cent chance of winning R15000 and a 50 per cent chance of winning nothing

Which of the following options do you prefer?

(c) a 20 per cent chance of winning R5 000

(d) a 10 per cent chance of winning R15 000 and a 10 per cent chance of winning nothing

\section{Endnotes}

1 The views expressed are those of the author and do not necessarily represent those of the South African Reserve Bank or Reserve Bank policy. The authors are grateful to the Department of Statistics at the University of Pretoria as well as to Dr J.J. van Tonder, 
retired staff member of the Department of Economics, University of Pretoria, for invaluable input and assistance.

2 Interested readers are referred to Alm and Martinez-Vazques (2003) for an account, which though not completely relevant to the current paper is interesting, of tax evasion in developing and transition countries.

3 Data was collected through survey/ questionnaires handed out in a class situation to first- and second-year Economics students taking the EKN120 and EKN 252 courses at the University of Pretoria.

\section{Bibliography}

1 ALLINGHAM, M.G. \& SANDMO, A. (1972)

"Income tax evasion: A theoretical analysis", Journal of Public Economics, 1: 323-338.

2 ALM, J; JACKSON, B.R. \& MCKEE, M. (1993) "Fiscal exchange, collective decision institutions and tax compliance", Journal of Economic Behaviour and Organization, 22: 285-303.

3 ALM, J. \& MARTINEZ-VAZQUEZ, J. (2003)

"Institutions, paradigms, and tax evasion in developing and transition countries," In MartinezVazquez, J. \& Alm, J. (eds.) Public Finance in Developing and Transitional Countries. Edward Elgar: United Kingdom.

4 CARROLL, J.S. (1992) "How taxpayers think about their taxes: Frames and values", In Slemrod, J. (ed.) Why People Pay Taxes: Tax Compliance and Enforcement. University of Michigan Press: Ann Arbor.

5 DIAMOND, P.A. \& MIRRLEES, J. (1971) "Optimal taxation and public production", American Economic Review, 61: 8-27, 261-278.

6 DIXIT, A. \& NORMAN, V. (1980) The Theory of International Trade. Cambridge University Press: London.

7 EC (EUROPEAN COMMUNITIESCOMMISSION) (1997) "Conclusions of the ECOFIN Council Meeting on 1 December 1997 concerning taxation policy (including Code of Conduct for business taxation)." Official Journal of the European Communities, 98(C2): 1.

8 ECONOMIST, THE (2000) A Survey of Globalisation and Tax, January 29: 1-18.

9 ELFFERS, H. \& HESSING, D.J. (1997) "Influencing the prospects of tax evasion", Journal of Economic Psychology, 18: 289-304.
10 FRENKEL, J.A.; RAZIN, A. \& SADKA, E. (1991) International Taxation in an Integrated World. MIT Press: Cambridge, MA.

11 GROENLAND, E.A. \& VAN VELDHOVEN, G.M. (1983) "Tax evasion behaviour a psychological framework", Journal of Economic Psychology, 3: 129-144.

12 JORGENSON, D.W. (1963) "Capital theory and investment behaviour", American Economic Review, 53(2): 247-259.

13 KAHNEMAN, P. \& TVERSKY, A. (1979) "Prospect theory, an analysis of decision-making under risk", Econometrica, 47: 263-92.

14 KATZ COMMISSION (1994) Interim Report of the Commission of Inquiry into Certain Aspects of the Tax Structure of South Africa. Government Printer: Pretoria:

15 KING, S.A. \& SHEFFRIN, S.M. (2002) “Tax evasion and equity theory: An investigative approach", International Tax and Public Finance, 9: 505-521.

16 KINSEY, K.A. (1984) Theories and Models of Tax Cheating. American Bar Foundation: Chicago.

17 KIRCHLER, E. (1998) "Differential representations of taxes: Analysis of free associations and judgements of five employment groups", Journal of Socio-Economics, 27(1): 117-131.

18 KIRCHLER, E. \& MACIEJOVSKY, B. (2001) "Tax compliance within the context of gain and loss situations, expected and current asset position, and profession", Journal of Economic Psychology, 22: 173-194.

19 KLEPPER, S. \& NAGIN. (1989) "The criminal deterrence literature: Implications for research on taxpayer compliance," In Roth, J.A. \& Scholtz, J.T. (eds.) Taxpayer Compliance, Social Science Perspectives, University of Peninsula Press: Philadelphia, PA. pp.126-155

20 LEWIS, A. (1982) The Psychology of Taxation. Oxford: Martin Robertson.

21 LEWIS, A., WEBLEY, P. \& FURNHAM, A. (1995) The New Economic Mind: The Social Psychology of Economic Behaviour. Harvester: New York.

22 NEWBERRY, B. \& STERN, N. (1987) Economic Development, Discussion paper, London School of Economics. LSE: London.

23 NTSA (NATIONAL TREASURY OF SOUTH AFRICA) (2003) Budget Review, NTSA: Pretoria.

24 NTSA (NATIONAL TREASURY OF SOUTH AFRICA) (2005) Budget Review, Pretoria: NTSA.

25 OECD (ORGANISATION FOR ECONOMIC COOPERATION AND DEVELOPMENT). 
(1991) Taxing Profits in a Global Economy: Domestic and International Issues. OECD: Paris.

26 OECD (ORGANISATION FOR ECONOMIC COOPERATION AND DEVELOPMENT) (1998) Harmful Tax Competition: An Emerging Global Issue. OECD: Paris.

27 OECD (Organisation for Economic Cooperation and Development) (2002) Access for Tax Authorities to Information Gathered by Anti-Money Laundering Authorities. http://www.oecd.org. (Accessed 20 April 2007)

28 SARS (SOUTH AFRICAN REVENUE SERVICE) (2004) Annual Report 2004, http://www. sars.gov.za. (Accessed 20 April 2007).

29 SCHNEIDER, F. \& ENSTE, D.H. (2000) "Shadow economies: Size, causes, and consequences," The Journal of Economic Literature, 38: 77-114.

30 SMITH, A. (1776) An Inquiry into the Nature and Causes of Wealth of Nations. JM Dent and Sons: London.

31 SMITH, K.W. \& KINSEY, K.A. (1987)

"Understanding taxpaying behaviour: A conceptual framework with implications for research", Law and Society Review, 21: 639-663.

32 SOUTH AFRICA. (1962) Income Tax Act, Act No. 58 of 1962. http://www.sars.gov.za. (Accessed 20 April 2007).

33 TANZI, V. (1996) "Globalization, tax competition and the future of tax systems", IMF Working Paper, IMF: Washington D.C.
34 TANZI, V. \& SHOME, P. (1993) "A primer on tax evasion”, IMF Staff Papers, 40(4): 807-828.

35 TANZI, V. \& ZEE, H.H. (2001) "Tax policy for developing countries”, IMF Economic Issue Series, No 27, IMF: Washington D.C.

36 TRIVEDI, V.U., SHEHATA, M. \& MESTELMAN, S. (2005) "Attitutes, incentives and tax compliance", Canadian Tax Journal, 53(1): 29-61.

37 TVEDE, M. \& GHIGLINO, C. (1999) "Optimal policy in OG models", Journal of Economic Theory, 90: 62-83.

38 UNCTAD (UNITED NATIONS CONFERENCE ON TRADE AND DEVELOPMENT) (1998)

World Investment Report 1998: Trends and Determinants. United Nations: New York and Geneva.

39 VOGEL, J. (1974) "Taxation and public opinion in Sweden: An interpretation of recent survey data", National Tax Journal, 27: 499-513.

40 VON NEUMANN, J. \& MORGENSTEIN, O. (1944) Theory of Games and Economic Behaviour. Princeton University Press: Princeton, NJ.

41 WARNERYD, K.E. \& WALERUD, B. (1982) "Taxes and economic behaviour: Some interview data on tax evasion in Sweden", Journal of Economic Psychology, 2:187-211.

42 WORLD BANK. (2000) Entering the 21 ${ }^{\text {st }}$ Century: World Development Report 1999/2000, Oxford University Press: New York. 